Mariusz Wysokiński ${ }^{1}$

Wiesław Fidecki ${ }^{1}$

Sylwia Bernat-Kotowska ${ }^{1}$

Robert Ślusarz ${ }^{2}$

\title{
HEALTH BEHAVIOUR OF MINERS
}

\author{
ZACHOWANIA ZDROWOTNE GÓRNIKÓW
}

${ }^{1}$ Medical University of Lublin / Uniwersytet Medyczny w Lublinie, Lublin, Poland

Chair of Nursing Development / Katedra Rozwoju Pielęgniarstwa

${ }^{2}$ Collegium Medicum in Bydgoszcz / Collegium Medicum w Bydgoszczy, Bydgoszcz, Poland

Neurological and Neurosurgical Nursing Department / Zakład Pielęgniarstwa Neurologicznego i Neurochirurgicznego

\begin{abstract}
Background: What significantly affects the health of an individual health behaviour. It is of particular importance in the case of people working in very harsh environmental conditions. The aim of this study is to examine health behaviour among miners. Material and Methods: The research data was collected with the use of the diagnostic survey method based on the Health Behaviour Inventory questionnaire developed by Juczyński. Two hundred coal miners were surveyed. The results obtained were subjected to a statistical analysis. A significance level of $\mathrm{p}<0.05$ was assumed, which indicates the occurrence of statistically significant differences or relations. Results: The level of health behaviour among miners may be determined as medium and low. The research group obtained the best results with regard to their mental attitude, while their preventive behaviour received the worst evaluation. Conclusions: The research confirms the necessity of implementing health promotion programmes among miners, which would be focusing particularly on health behaviour. Med Pr 2015;66(6)
\end{abstract}

Key words: health promotion, miners, healthy behaviour

\section{STRESZCZENIE}

Wstęp: Elementem istotnie wpływającym na stan zdrowia jednostki są jej zachowania zdrowotne. Szczególnie rolę odgrywają w przypadku osób wykonujących pracę zawodową w bardzo trudnych warunkach środowiskowych. Dlatego celem pracy było zbadanie zachowań zdrowotnych górników. Materiał i metody: W pracy wykorzystano metodę sondażu diagnostycznego w oparciu o kwestionariusz Inwentarza Zachowań Zdrowotnych Juczyńskiego. Badaniami objęto 200 górników kopalni węgla kamiennego. Uzyskane wyniki badań poddano analizie statystycznej. Za poziom istotności przyjęto $\mathrm{p}<0,05$ wskazujący na istnienie istotnych statystycznie różnic bądź zależności. Wyniki: Zachowania zdrowotne górników kształtują się na poziomie średnim i niskim. Najlepsze wyniki badana grupa uzyskała w zakresie nastawienia psychicznego, a najgorzej ocenione zostały zachowania profilaktyczne. Wnioski: Badania potwierdzają konieczność wdrażania programów promocji zdrowia wśród górników szczególnie ukierunkowanych na zachowania zdrowotne. Med. Pr. 2015;66(6)

Słowa kluczowe: promocja zdrowia, górnicy, zachowania zdrowotne

Corresponding author / Autor do korespondencji: Mariusz Wysokiński, Medical University of Lublin, Chair of Nursing Development, ul. Staszica 4-6, 20-081 Lublin, Poland, e-mail: mariusz.wysokinski@umlub.pl

Received: September 16, 2014, accepted: February 23, 2015

\section{INTRODUCTION}

Health behaviour is an important concept in the area of health promotion. Hence, it constitutes an important theoretical and practical problem, requiring a multifaceted approach, i.e., psychological, sociological and medical. Available research concerning the definition of health behaviour shows that a consistent terminology of the notion is yet to be laid down. Every study in this area adopts unique nomenclature for health-related behaviour, ranging from health behavio- ur as such, through sickness behaviour, health practices, pro-health lifestyle, behaviour conducive to health, anti-health behaviour, risky health behaviour, to medical behaviour. It can be inferred from the analysis of various definitions of health behaviour that people themselves make informed choices with respect to their behaviour, having many alternatives at hand which may affect their health in a positive or a negative way [1-10].

Health behaviour determinants include age, gender, life objectives, social context (e.g., social background, 
education, place of residence, affluence) and cultural background (e.g., family customs and traditions) [1].

Titkow identifies 5 major categories of health behaviours: health maintenance-driven behaviours, such as hygiene habits, behaviours resulting from assuming the role of a sick person, behaviours in patient's environment such as a response to sickness symptoms, alternative sources of assistance in sickness, and adhering to the role of a sick person [10].

Issues presented in this paper are all the more significant as the specific nature of the miner's job is characterised by heavy physical work in difficult conditions and may result in serious health effects, including occupational diseases or injuries [11-13]. Rudimentary issues presented in the study seem highly relevant and due to a specific character of the miner's job are typified by a considerable physical and psychological strain and exposition to numerous harmful factors, such as high temperature and dust.

In Poland, the average incidence proportion for occupational diseases in the mining industry is the highest in comparison with other professional groups [14]. Working underground may also have a noticeable impact on the hormonal system or several physiological parameters and even the lipid profile $[15,16]$. Consequently, the research was administered among employees of the Lubelski Weqgiel "Bogdanka" - the only coal mine in the south-east Poland.

The aim of the study was to examine health behaviour of miners illustrated by employees of the Lubelski Węgiel "Bogdanka" coal mine company.

\section{MATERIAL AND METHODS}

Data was collected using the diagnostic survey method based on the Catalogue of Healthy Behaviour questionnaire developed by Juczyński [17]. The Catalogue of Healthy Behaviour (CHB) consists of 24 statements describing different types of health-related behaviour. They comprise 4 gradable health behaviour categories (5-point grading scale): correct eating habits, preventive actions, health practice and positive mental attitude. Correct dietary habits concern primarily the type of food consumed, e.g., wholemeal bread, fruit and vegetables. Preventive actions include such activities as adherence to health recommendations or obtaining information on health and diseases.

Daily sleep habits, recreation and physical activity are also included in the $\mathrm{CHB}$ statements. A positi- ve mental attitude refers to avoiding too strong emotions, stress, tensions, or depressing situations. While completing their questionnaires respondents state how often they perform specific health-related activities and mark each behaviour on the 5-point scale, where 1 stands for hardly ever, 2 - seldom, 3 - occasionally, 4 - frequently, and 5 - nearly always [17].

The study was conducted in compliance with the principles of the Helsinki declaration.

Tests were carried out in September 2012 among employees of the Lubelski Węgiel "Bogdanka" coal mine. Respondents freely agreed to participate in the study. They were informed about the method to complete the survey, its aim, as well as the intended use of the results obtained. Only those employed as miners could participate in the study. Respondents were given $10 \mathrm{~min}$ to provide their answers. The survey was administered in the premises of the Extramural Postgraduate Mining School of the Mining School Complex in Łęczna during miners' postgraduate complementary training so as to provide ample time and appropriate conditions for filling in questionnaires.

The research findings were subjected to a statistical analysis. Values of the measurable parameters were analysed using mean and standard deviation values, whereas the data concerning non-measurable parameters was presented using amount and percentage. The normality distribution of the measurable parameters analysed was assessed by means of the Shapiro-Wilk test. Student's t-test was utilised for the comparison of 2 independent groups. For more than 2 groups, analysis of variance was employed. Pearson's $r$ correlation was used as a tool to examine the link between variables. A significance level of $\mathrm{p}<0.05$ was assumed, which indicates the occurrence of statistically significant differences or relations. Database and statistical tests were carried out with Statistica 10.0 computer software (StatSoft, Poland).

The research cohort comprised 200 men aged 1942. The average age was $25.80 \pm 3.99$ years. The largest proportion of respondents were males aged 21-25, i.e., $39 \%$ (78 persons) and $26-30$, i.e., $34 \%$ (68 persons). Fifteen percent (30 persons) were below the age of 21 , while $12 \%$ ( 24 people) were above the age of 30 . Most respondents, namely $63 \%$ of them (125 people) lived in urban areas and 67\% (134 respondents) had obtained secondary education, 33\% (65 people) declared they had higher education, whereas 1 person had only primary education. 


\section{RESULTS}

In respect of the self-assessment survey conducted with regard to health behaviour among the Lubelski Węgiel "Bogdanka" coal mine employees with the use of $\mathrm{CHB}$, the results obtained indicate the average value of 72.71 points, with the standard deviation (SD) value at 12.08 points. Health behaviours of the survey respondents ranked mostly at sten score of 3-4 (47\%), which can be considered a low result. The very low results (1-2. sten) accounted for $20 \%$ of the total results, while average ones (5-6. sten) amounted to $29 \%$. High results amounted to merely $6 \%$ (7-10. sten).

In a detailed analysis of behaviour types, positive mental health was top rated $($ mean $(M)=3.40, S D=0.66)$, correct eating habits achieved lower results $(\mathrm{M}=2.83$,
$\mathrm{SD}=0.65)$, along with health practices $(\mathrm{M}=2.96$ $\mathrm{SD}=0.73)$ and preventive actions $(\mathrm{M}=2.94, \mathrm{SD}=0.69)$. There was no statistically significant difference indicated in the assessment of health behaviour among different age groups in particular subscales $(p>0.05)$. Statistical analysis has shown that the CHB indicator was noticeably higher in the 30+ age group (75.75) than in the below 21 age group (73.10), in males aged 22-25 (74.65) and $26-30$ years $(69.24)(p=0.02)$.

Respondents with a higher education background demonstrated better health behaviour than those with secondary or primary education. Statistically significant differences were noted in the health practices assessment $(p=0.001)$ and in the overall assessment of the CHB indicator $(\mathrm{p}=0.02)$, while there was no statistically significant difference in the assessment

Table 1. Health behaviours of miners

Tabela 1. Zachowania zdrowotne górników

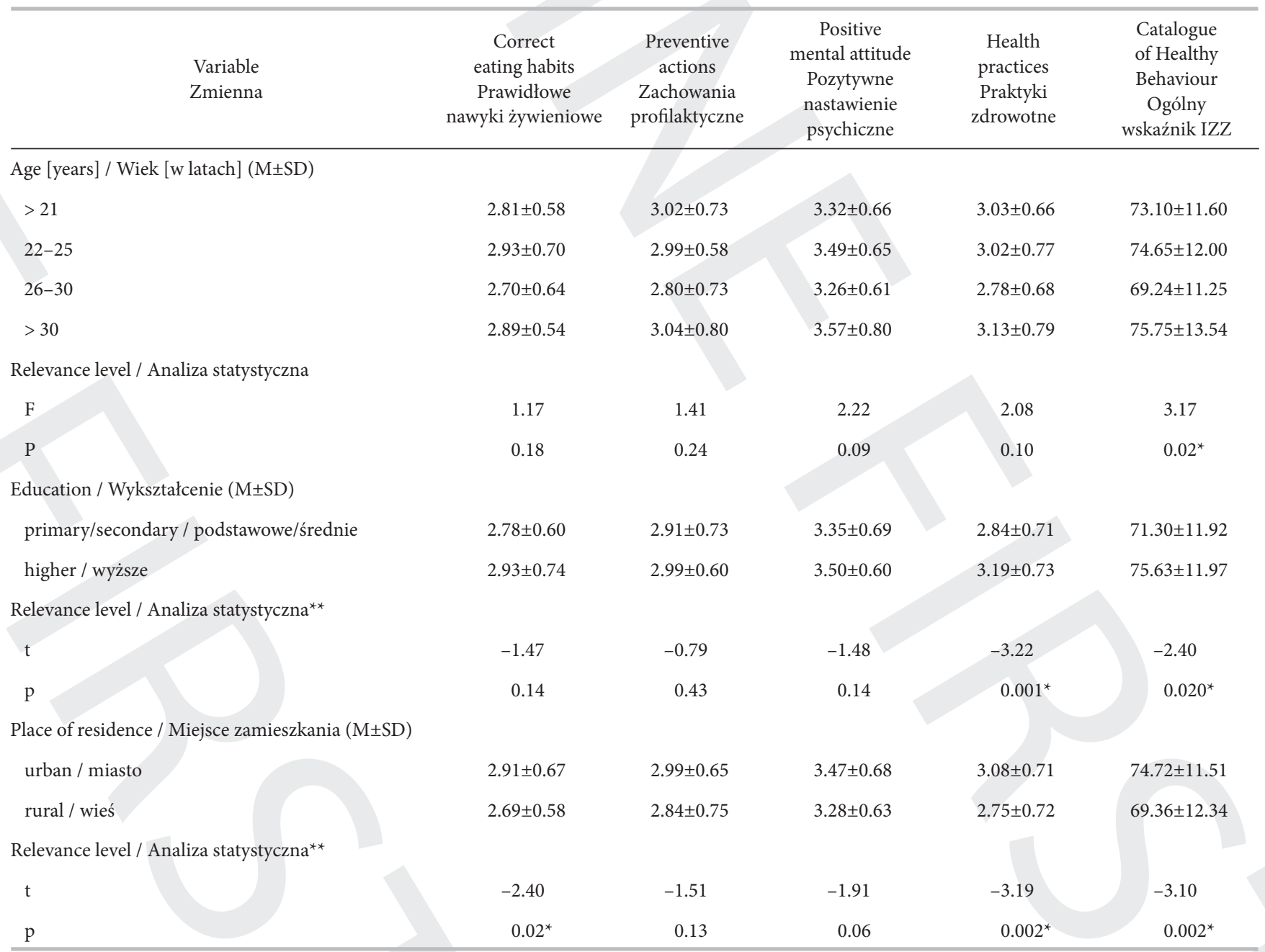

M - mean / średnia, SD - standard deviation / odchylenie standardowe, IZZ - Catalogue of Healthy Behaviour / Inwentarz Zachowań Zdrowotnych.

* Analysis of variance / analiza wariancji.

** Student's t test / test t-Studenta. 
of correct eating habits and positive mental health subscales $(p>0.05)$. City dwellers surveyed manifested better health behaviour in all subscales than respondents from rural areas. There was a visible discrepancy between those groups in the correct eating habits assessment $(p=0.02)$, health practices $(p=0.002)$ and in the assessment of the $\mathrm{CHB}$ indicator ( $\mathrm{p}=0.002)$. In the category of positive mental attitude, the difference also amounted to a level close to significance $(\mathrm{p}=0.06)$ (Table 1$)$.

\section{Characteristics of individual health behaviours}

For the assessment of correct eating habits, the following $\mathrm{CHB}$ items were selected:

no. 1 - "I eat a lot of fruit and vegetables,"

no. 5 - "I limit the consumption of such products as animal fats or sugar,"

no. 9 - "I care about proper nutrition,"

no. 13 - "I avoid foods containing preservatives,"

no. 17 - "I avoid salt and heavily salted food,"

no. 21 - "I eat wholemeal bread."

The survey shows that most respondents rarely cut down animal fats or sugar (44\%), nor foods containing preservatives (39\%), common salt and heavily salted food (38\%). Most respondents claimed to occasionally respect proper nutrition recommendations (40\%), eat wholemeal bread (43\%), fruit and vegetables (41\%) (Table 2). The survey showed, by means of Student's t-test, men living in urban areas to have better dietary habits in comparison with those from rural areas. Differences were found with respect to avoiding foods containing preservatives $(\mathrm{t}=-2.63 ; \mathrm{p}=0.01)$ and eating wholemeal bread $(t=-2.23 ; p=0.03)$. No statistically significant differences were found in assessing other components of the correct eating habits subscale. A correlation analysis failed to reveal any differences between levels of education or age and the correct eating habits.

Preventive health actions include the following items of the Catalogue of Healthy Behaviours:

no. 2 - "I avoid common colds,"

no. 6 - "I have telephone numbers of emergency medical services at hand,"

no. 10 - "I abide by medical recommendations resulting from the examinations undergone,"

no. 14 - "I regularly take medical examinations,"

no. 18 - "I try to be informed on how others avoid being ill,"

no. 22 - "I try to obtain medical information and understand the reasons of well-being and illnesses." Respondents seldom had emergency services' pho- ne numbers at hand (44\%) and hardly made regular appointments for their medical examination (34\%). Thirty seven percent took measures to avoid common colds. Thirty five percent declared to comply with medical recommendations. Thirty three percent tried to obtain medical information and understand causes for disease development and 32\% tried to learn how others avoid ailments (Table 2).

The study proved city dwellers to exhibit slightly better behaviour than respondents living in rural areas, with the exception of keeping emergency phone numbers at hand. Statistical analysis showed, by means of Student's t-test, significant differences in the assessment of compliance with medical recommendations resulting from medical examination taken $(t=-2.48$; $\mathrm{p}=0.01$ ), in the attempts to obtain medical information and the information on the sources of health and illness $(t=-2.06 ; p=0.04)$. There was no statistically significant difference between men from urban and rural areas in the assessment of remaining components of the preventive actions subscale.

Respondents with higher education claimed to undertake better preventive actions than men with primary or secondary education with the exception of the statement "I have telephone numbers of emergency medical services at hand." Statistical analysis showed, by means of Student's t-test, significant differences in the assessment of compliance with medical recommendations resulting from medical examination taken $(\mathrm{t}=-2.48 ; \mathrm{p}=0.01)$, while in other aspects assessed, educational differences between groups were rather insubstantial.

With age, men seem to pay less attention to keeping emergency phone numbers at hand. There is, however, no visible link between age and other components of preventive behaviours.

The assessment of positive mental attitude criterion was based on the following items of the $\mathrm{CHB}$ questionnaire:

no. 3 - "I consider others' concerns about my health,"

no. 7 - "I avoid depressing situations,"

no. 11 - "I try to avoid too strong emotions, stress, tensions,"

no. 15 - "I have friends and a settled family life,"

no. 19 - "I avoid emotions like anger, fear or depression,"

no. 23 - "I think positively."

The research shows that most respondents occasionally treat people expressing concern about their health seriously (31\%) and also seek to avoid strong emo- 
Table 2. Frequency of respondents' adopting specific health behaviours

Tabela 2. Częstotliwość podejmowania poszczególnych zachowań zdrowotnych przez badanych

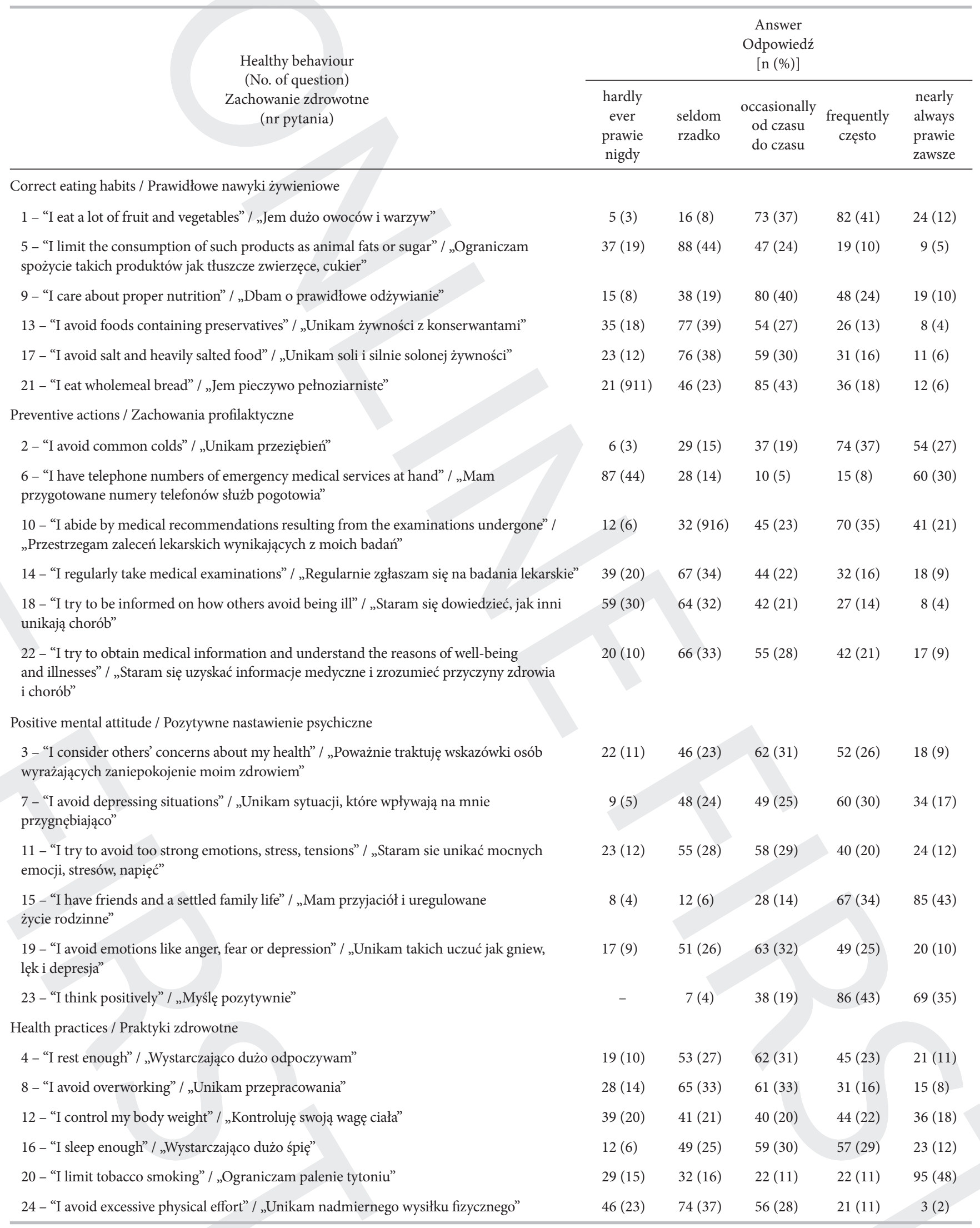


tions, stress and tensions (29\%) and feelings such as anger, fear and depression (32\%). Respondents often claimed to avoid situations which had a depressing influence (30\%), and to keep a positive attitude (43\%). In most cases, respondents had friends and a settled family life (34\%) (Table 2). Men living in urban areas paid more attention to avoiding depressing situations (Student's t-test, $\mathrm{t}=-2.49 ; \mathrm{p}=0.01$ ) and sought to avoid strong emotions, stress and tensions $(t=-3.15$; $\mathrm{p}=0.002$ ) more than respondents from rural areas.

There was no statistically significant difference between both groups with regard to remaining components of the positive mental health subscale. Persons with higher education showed a slightly more positive attitude than those with secondary or primary education. Statistical analysis, however, did not reveal significant differences between educational groups in the evaluation of their positive mental attitude. No significant correlations were found between assessments of specific questions comprising the positive mental attitude and respondents' age.

The following $\mathrm{CHB}$ questionnaire items were taken into account for the assessment of respondents' health practices:

no. 4 - "I get enough rest,"

no. 8 - "I avoid overworking,"

no. 12 - "I control my body weight,"

no. 16 - "I get enough sleep,"

no. 20 - "I limit tobacco smoking,"

no. 24 - "I avoid excessive physical effort."

In the case of question $4,31 \%$ of the research cohort declared they occasionally get enough rest, 30\% have enough sleep (question 16). Answering question 8, $37 \%$ of the research cohort declared they undertook excessive physical effort and 33\% claimed to get overworked frequently (question 24). Twenty two percent frequently controlled their body weight (question 12). Forty eight percent of the research group declared they nearly always tried to reduce their smoking (Table 2).

By means of Student's t-test, statistically significant differences were noted in the assessment of the following statements: "I get enough rest" $(\mathrm{t}=-3.22$; $p=0.002)$, "I avoid overworking" $(t=-2.85 ; p=0.005)$, "I get enough sleep" ( $\mathrm{t}=-3.01 ; \mathrm{p}=0.003)$, and "I limit smoking" $(\mathrm{t}=-2.07 ; \mathrm{p}=0.04)$. There was, however, no statistically significant difference in the assessment of body weight and avoiding excessive physical effort. The rate of health practices was higher among respondents with a higher education background than among those with secondary or primary education.
Statistically significant differences were found between education groups with respect to the assessment of sufficient sleep $(\mathrm{t}=-3.26 ; \mathrm{p}=0.001)$ and smoking limits $(t=-2.96 ; p=0.004)$, while there was no substantial difference in the assessment of other components of the health practices subscale. Correlation analysis revealed a noteworthy link between age and avoiding excessive physical effort $(r=0.20)$. With age, men limited their physical effort. There was no considerable link between age and the other constituents of health practices.

\section{DISCUSSION}

No previous research devoted to the issue studied in this paper was found in the available databases. It is therefore impossible to compare the test results obtained with other studies related to health behaviour of miners. Available study papers generally focus on selected aspects of the field, such as preventive studies or eating habits $[18,19]$.

Through a comparison of results obtained from the survey with research findings of Juczyński [17] - the creator of the tool utilised herein, it was determined that the difference with respect to dietary habits did not prove to be statistically significant $(\mathrm{p}=0.39)$, whereas preventive actions were noticeably worse in comparison with the reference group ( $\mathrm{p}<0.0001)$. Positive mental attitude assessment, however, obtained significantly better results $(\mathrm{p}=0.006)$. The reference group gained slightly better results in health practices assessment $(p=0.07)$. General CHB index was significantly better in the reference group $(p<0.0001)$. Nevertheless, it must be noted that the Author of the tool does not provide detailed demographic data of the standardization group. He only states that the group was diverse with respect to members' environment (Table 3).

Health practice studies carried out on other groups have shown that the miners surveyed obtained a lower average point value score than e.g., the elderly (83.288.39), patients with cardiovascular diseases (78.31), patients with type 2 diabetes (92.92), or women who had undergone mastectomy (86.09) [12,15,16,20,21]. On a sten scale, the results obtained (3-4) were also lower than those of the obese and overweight (5-6. sten) [20]. Nonetheless, one must bear in mind the constraints of such comparisons as health behaviours of people with various illnesses might be determined by their diagnostic process, or their treatment process which often for- 
Table 3. Comparison of the results obtained with the reference group's results

Tabela 3. Porównanie uzyskanych wyników z wynikami grupy referencyjnej

\begin{tabular}{lcc}
\hline \multicolumn{1}{c}{$\begin{array}{c}\text { Health behaviour } \\
\text { Zachowanie zdrowotne }\end{array}$} & $\begin{array}{c}\text { Study group } \\
\text { Grupa badana } \\
(\mathrm{N}=200) \\
(\mathrm{M} \pm \mathrm{SD})\end{array}$ & $\begin{array}{c}\text { Reference group } \\
\text { Grupa referencyjna } \\
(\mathrm{N}=235) \\
(\mathrm{M} \pm \mathrm{SD})\end{array}$ \\
\hline Correct eating habits / Prawidłowe nawyki żywieniowe & $2.83 \pm 0.65$ & $2.85 \pm 0.79$ \\
Preventive actions / Zachowania profilaktyczne & $2.94 \pm 0.69$ & $3.30 \pm 0.77$ \\
Positive mental attitude / Pozytywne nastawienie psychiczne & $3.40 \pm 0.66$ & $3.24 \pm 0.66$ \\
Health practices / Praktyki zdrowotne & $2.96 \pm 0.73$ & $3.08 \pm 0.95$ \\
Catalogue of Healthy Behaviours / Ogólny wskaźnik IZZ & $72.71 \pm 12.08$ & $78.50 \pm 14.02$ \\
\hline
\end{tabular}

Abbreviations as in Table 1 / Skróty jak w tabeli 1.

ces adopting positive health behaviours. Furthermore, such studies fail to account for specific circumstances of respondents' professional backgrounds.

A detailed analysis of the criteria used to determine health behaviours in miners showed they obtained the highest average scores in the category of mental attitude (3.40). This category also received the best average score in persons with cardiovascular diseases and in elderly people (3.43) [21,22], and in patients with type 2 diabetes, or in women who had undergone mastectomy [23], or patients with lower extremity arterial disease $[24,25]$. Optimistic mental attitude might influence the miners' perception of their physical and mental health. It also had an impact on their functioning in their community and their professional career [26]. Conceivably, this might be a reason why there were no intensified efforts visible with respect to health prevention and practices, since miners might consider their health status to be high, despite low results in other criteria. Interestingly enough, optimists were usually eager to apply rules of preventive methods and health promotion [26].

The surveyed miners obtained the lowest average score in the category of preventive behaviours (2.94). This score was lower than those of patients suffering from chronic illnesses, where health education and prevention of complications play an important role, such as cardiovascular diseases (3.36), type 2 diabetes (3.65), and post-mastectomy pain syndrome $[22,24,25]$. These results may raise concern not only with regard to prevention of occupational diseases in miners, but also because of the most frequent cause of natural death among them, i.e., myocardial infarction in advanced diabetes mellitus or ischaemic heart disease, which occur not only due to a particular work environment, but also as a consequence of a specific lifestyle, diet, smoking, drinking, and stress level [19]. Thus, prevention aimed at limiting the impact of the aforementioned factors is of great importance, but in fact, studies prove that it is not a subject of interest for miners themselves.

In the test group surveyed in this study, the highest average score with respect to health behaviour was obtained by respondents aged over 35 . In contrast, the impact of education level was confirmed in some categories of health behaviours $[22,23,27]$.

Moreover, there was a visible disparity between the eating style prevalent among miners and actual recommendations relating to pro-health behaviours. This is because they rarely restricted their consumption of animal fats, sugars or food preservatives. Fruit and vegetables were insignificant components of a healthy diet among miners, which might prove that they lacked basic knowledge of proper nutrition. Miners were familiar with the notion itself, but when it came to specific content, their information was deficient.

As regards preventive actions, few respondents regularly underwent their medical examination. Ignoring recommendations of people showing an interest in their health was common. A basic preventive practice indicated in the survey was avoiding common colds. Restricting preventive behaviours only to avoiding common colds might result from a lack of occupational medicine centre situated within their mine.

It is worth noting that limited smoking was a recurring pro-health behaviour. It could be a result of efficient awareness campaigns and institutional activities aiming to decrease the prevalence of this addiction. Miners also sought to restrict excessive physical effort and stress. 


\section{CONCLUSIONS}

1. Miners showed a low level of health behaviour.

2. The research proved that there was a need for health promotion programmes addressed to this particular professional group. Such programmes should concentrate on health behaviours with respect to the specific nature of the job performed.

3. It is advisable to include the research on health behaviour in Polish miners in the international research devoted to this issue.

\section{REFERENCES}

1. Andruszkiewicz A, Banaszkiewicz M. [Health promotion for nursing and obstetrics undergraduate students. Volume I. Theoretical fundaments for health promotion]. Lublin: Wydawnictwo Czelej; 2008. Polish.

2. Bartoszek A, Ostrowska-Ogórek M. [Health behaviours of elderly people]. Pieleg Polozna 2002;3:21-3. Polish.

3. Cianciara D. [Contemporary health promotion - An outline]. Warszawa: Wydawnictwo Lekarskie PZWL; 2010. Polish.

4. Gniazdowski A. [Health behaviours: Theory and attempt to characterise health behaviours in the Polish society]. Łódź: Instytut Medycyny Pracy; 1990. Polish.

5. Latalski M. [Public health]. Lublin: Akademia Medyczna w Lublinie; 1999. Polish.

6. Taranowicz I, Majchrowska A, Kawczyńska-Butrym Z. [Elements of sociology for nurses]. Lublin: Wydawnictwo Czelej; 2000. Polish.

7. Titkow A. [Behaviours and attitudes towards health and illness. Study Warsaw]. Warszawa: PWN; 1983. Polish.

8. Tobiasz-Adamczyk B. [Selected elements of health and illness sociology]. Kraków: Wydawnictwo Uniwersytetu Jagiellońskiego; 1998. Polish.

9. Woynarowska B. [Health behaviours]. Pediatr Praktycz. 1999;7(2):177-81. Polish.

10. Barański J, Piątkowski W. [Health and illness. Selected issues of medicine sociology]. Wrocław: Oficyna Wydawnicza ATUT - Wrocławskie Wydawnictwo Oświatowe; 2002. Polish.

11. Adamek R, Witokowska A, Zysnawska M. [Occupational disease risk in "Kłodawa" Salt Mine]. Hyg Public Health. 2010;45(2):202-5. Polish.

12. Bhattacherjee A, Kunar BM, Bauman M, Chau N. [The role of occupational activities and work environment in occupational injury and interplay of personal factors in various age groups among Indian and French coalminers]. Int J Occup Med Environ Health. 2013;26(6):910-29.
13. Graber JM, Cohen RA, Basanets A, Stayner LT, Kundiev Y, Conroy L, et al. [Results from a Ukrainian - US collaborative study: Prevalence and predictors of respiratory symptoms among Ukrainian coal miners]. Am J Ind Med. 2012;55(12):1099-109.

14. Szeszenia-Dąbrowska N, Wilczyńska U. [Occupational diseases among workers in the various branches of the domestic economy]. Med Pr. 2013;64(2):161-74. Polish.

15. Kalinowska AK, Mirska A, Dmitruk E. [Subterraneotherapy as a climate therapy]. Acta Balneol. 2013;55(1): 55-8. Polish.

16. Tumińska A, Borodulin-Nadzieja L, Pietraszkiewicz T, Salomon E, Stańda M, Woźniak W, et al. [Analysis results of Holter monitoring diagnosis in deep underground miners in copper mines of the Legnica-Głogów Copper Mining District]. Med Pr. 2010;61(1):43-54. Polish.

17. Juczyński Z. [Measuring tools in health promotion and psychology]. Warszawa: Pracownia Testów Psychologicznych Polskiego Towarzystwa Psychologicznego; 2001. Polish.

18. Shibanova NY. [Hygienic problems of Kusbass miners nutrition]. Vopr Pitan. 2007;76(5): 43-7. Russian.

19. Skowronek R, Chowaniec C, Kowalska A. [Cardiac deaths in mining as an efficiency indicator of occupational medicine]. Arch Med Sad. 2011;61(1):29-34. Polish.

20. Kawalec E, Reczek A, Porębska A, Brzostek T, Malinowska-Lipień I. [Health behaviours in obese and overweight patients]. Pieleg XXI w. 2011;2(35):27-33. Polish.

21. Smoleń E, Gazdowicz L, Żyłka-Reut A. [Health behaviours of elderly people]. Pieleg XXI w. 2011;3(36):5-9. Polish.

22. Ślusarska B, Nowicki G. [Health behaviours in cardiovascular disease prevention in professionally active people]. Probl Hig Epidemiol. 2010;91(1):34-40. Polish.

23. Pacian A, Kulik BT, Skórzyńska H, Chruściel P, Stefanowicz A, Dąbrowska A. [Health factors among women after mastectomy]. Przegl Menopauz. 2013;17(5):392-8. Polish.

24. Kurowska K, Szomszor M. [Impact of health behaviour on life quality of patients with type 2 diabetes]. Diabetol Prakt. 2011;12(4):142-150. Polish.

25. Kurowska K. [Health behaviour and life quality of patients with lower extremity arterial disease]. Pieleg Chirurg Angiolog. 2013;3:107-14. Polish.

26. Potemba K. [Optimism and health]. Med Ogolna Nauki Zdrow. 2013;19(2):130-4. Polish.

27. Muszlik M, Zielińska-Więczkowska H, Kędziora-Kornatowska $\mathrm{K}$, Korantowski T. [Assessment of selected 
health promoting behaviours in elderly people on the basis of Juczyński's Health Behaviour Inventory with respect to socio-demographic factors]. Probl Hig Epidemiol. 2013;94(3):509-3. Polish.
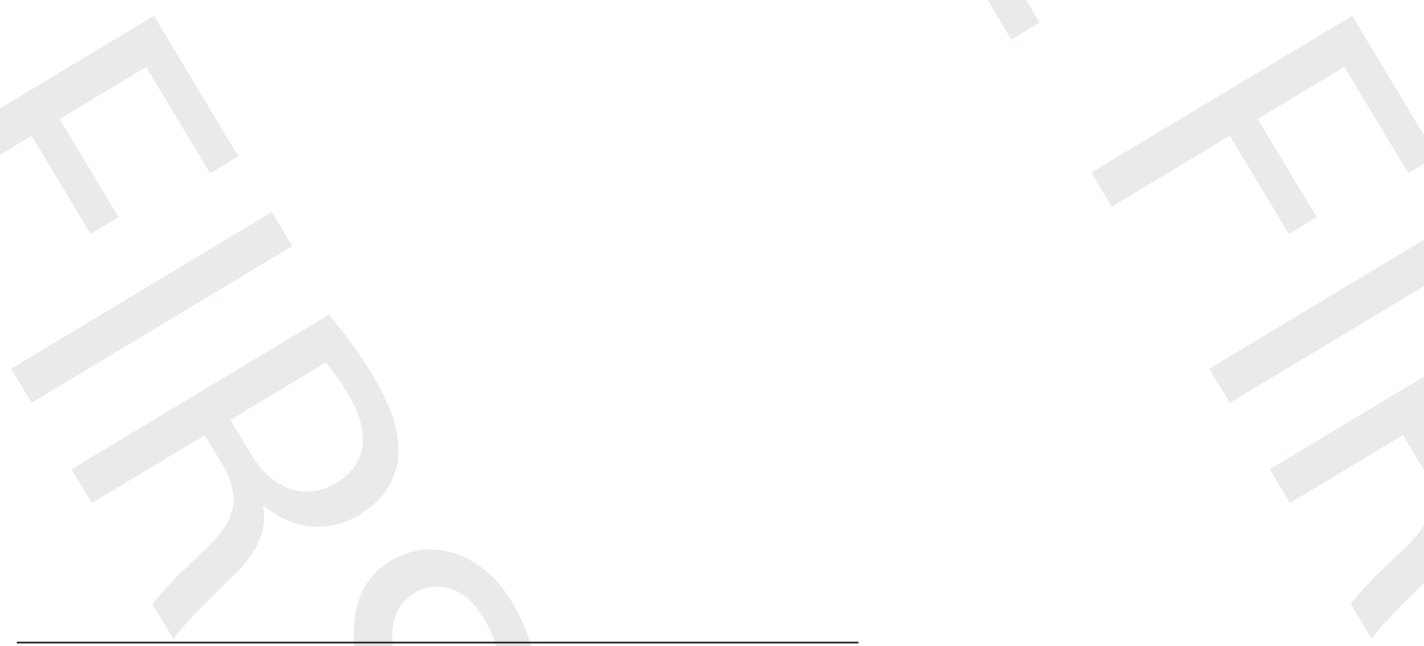

The use of the article "Health behaviour of miners" is available in Open Access model and permitted under license conditions of Creative Commons Attribution-Noncommercial 3.0 (also known as CC-BY-NC), available at http://creativecommons.org/licenses/by-nc/3.0/pl/deed.en or another language version of this license or any later version of this license published by Creative Commons / Zezwala się na korzystanie z artykułu „Zachowania zdrowotne górników" w modelu open access na warunkach licencji Creative Commons Uznanie autorstwa - Użycie niekomercyjne 3.0 (znanej również jako CC-BY-NC), dostępnej pod adresem http://creativecommons.org/licenses/by-nc/3.0/pl/ lub innej wersji językowej tej licencji lub którejkolwiek późniejszej wersji tej licencji, opublikowanej przez organizację Creative Commons. 